\title{
EFFECT OF PROTECTED SOYBEAN MEAL ON MILK YIELD AND COMPOSITION IN LOCAL MERIZ GOATS
}

Kamal N. S. Dosky, Shana S. A. Jaaf and Layla T. Mohammed

Dept. of Animal Production, College of Agriculture, University of Duhok. Duhok, Iraq

\begin{abstract}
The objective of this study was to evaluate the effect of protected soybean meal (SBM) on total milk yield (TMY) and composition, milk energy and body weight (BW) in lactating Meriz does. Eighteen does (BW 33.13 \pm 0.41 $\mathrm{Kg}$ ) were randomly divided into two equal groups, control (untreated soybean meal) (C) and the treated soybean meal chemically treated with formaldehyde (T). Results revealed that protected soybean meal significantly $(\mathrm{P}<0.001)$ increased TMY (44.20 vs $34.08 \mathrm{~kg}$ ), milk fat \% (4.14 \pm 0.13 vs $3.32 \pm 0.06)$, and yield $(25.45 \pm 0.75$ vs $16.08 \pm 0.41 \mathrm{gm} /$ day $)$, milk protein $\%(4.86 \pm 0.05$ vs $4.31 \pm 0.04)$, and yield $(30.73 \pm 1.02$ vs $20.99 \pm 0.52 \mathrm{gm} /$ day), and milk energy $(3.38 \pm 0.05$ vs $3.03 \pm 0.02 \mathrm{MJ} / \mathrm{kg})$ as compared to control. It can be concluded that protection process of soybean meal increased milk yield, fat and protein content.
\end{abstract}

\section{INTRODUCTION}

Protecting high-quality protein sources, such as legumes and seed meals from ruminal fermentation positively affects animal performance. Various methods for treating proteins have been used to reduce their degradation in the rumen. These can be broadly categorized as chemical and physical treatments (Mir et al., 1984). Chemical treatments can further be divided into methods in which the chemicals actually combine with the proteins, e.g., formaldehyde treatment, and those in which the chemicals denature the proteins, e.g., treatment with alcohol, sodium hydroxide, and propionic acid (Oldham, 1984; Varvikko et al., 1983). Furthermore, formaldehyde can affect microorganism activities and consequently alter digestion (Mustafa et al., 2000). Soybean meal (SBM) is the most commonly used protein supplement in broiler, beef and dairy rations. It is quite palatable and has a good amino acid balance with high availability (Yoruk et al., 2006). The impact of protected soybean meal on milk production was studied in goats, by Chowdhury et al., (2002), El-Shabrawy (2006), who reported an increase in milk yield in goats fed formaldehyde treated soybean meal compared to those fed untreated soybean meal. Moreover, Dosky (2007), Kassem et al., (2007) and Salih (2009) noted an increase in milk yield of ewes fed formaldehyde protected soybean meal. On the other hand, Brun-Bellut et al., (1990) showed that milk yield and milk nitrogen content did not change.Meriz is a native goat to Kurdistan region and raised mainly for its fine hair as well as for meat and milk production (Alkass and Juma, 2005). Earlier studies reported that total milk yield of Meriz goat was 104.82 and $107.72 \mathrm{~kg}$ for a lactation periods of 128 and 131.11 days, respectively (Shams El-deen, 2005; 2006). However, no information is available on the effect of protected protein in lactating Meriz does. Therefore, the main objective of this study was to investigate the influence of feeding protected protein of soybean meal on milk yield and composition of this breed.

\section{MATERIALS AND METHODS}


Mesopotamia J. of Agric. $\quad$ ISSN: 2224-9796 (online)

Vol. (40) No.(1)2012

ISSN: $1815-316 \mathrm{X}$ (print)

The present study was carried out at the animal farm, Animal Production Department, College of Agriculture, University of Duhok during the kidding season 2010.

Received 31/10/2010 accepted 25/3/2011 
Eighteen Meriz does with an average weight $(33.13 \pm 0.41 \mathrm{Kg})$ were divided into two equal groups $(\mathrm{n}=9)$. Each group was housed in individual pens $\left(2.5 \times 2.5 \mathrm{~m}^{2}\right)$ and grazed daily from 7.0 am to $2.0 \mathrm{pm}$. In addition the animals were fed $900 \mathrm{gm} / \mathrm{head} /$ day concentrate ration (Table 1 ). The vitamins were mixed with concentrate as an additive. Soybean meal (15\% of ration) were treated with formaldehyde solution according to Kassem et al.,(1987). Feedstuffs were chemically analyzed according to Anonymous (1980). Goats were weighed at the beginning through biweekly interval during the experimental period. Clean water was available constantly.

Table (1): Ingredient and chemical composition of diet $\%$.

\begin{tabular}{|c|c|c|c|c|c|}
\hline \multirow{2}{*}{ Items } & \multirow{2}{*}{ Control } & \multirow{2}{*}{ Treatment } & \multicolumn{3}{|c|}{ Chemical analysis \% } \\
\cline { 4 - 6 } & & & & Control & Treatment \\
\hline Treated Soybean meal & ----- & 15 & Dry matter* & 92.98 & 92.96 \\
\hline Untreated Soybean meal & 15 & ---- & Crude protein* & 14.9 & 14.8 \\
\hline Barley & 60 & 60 & Ether extract* & 3.98 & 4.1 \\
\hline Wheat bran & 15 & 15 & Organic matter* & 95.17 & 95.24 \\
\hline Wheat straw & 9 & 9 & Ash* $^{*}$ & 4.83 & 4.76 \\
\hline Salts & 0.5 & 0.5 & Crude fiber ** & 10.17 & 10.17 \\
\hline Limestone & 0.5 & 0.5 & NFE ** & 63.71 & 63.71 \\
\hline
\end{tabular}

* Determined at nutrition Lab., Animal Production Dept. ** Calculated according to AlKhawaje et al., (1978).

Kids remained with their mothers till weaning except for the time when milk yield was recorded. During the pre-weaning period milk yield was recorded at biweekly starting two weeks post kidding. Kids were separated from their mothers at $4.00 \mathrm{pm}$ and weighed at 10.00 am next morning, then allowed to suckle their mothers till they stop suckling and were weighed again to find out the amount of milk suckled. Then the kids were separated again from their dams at 10.15 a.m till $6.15 \mathrm{p} . \mathrm{m}$ when the same procedure was applied to find out the total daily milk yield.

Milk samples $(40 \mathrm{ml})$ were collected from does by hand milking from both sides of the udder. The milk components were determined by using automatic analyzer (EKO-MILK Ultrasonic milk analyzers). Milk energy values were calculated according to Economides, (1986) using the following equation: Calorific value $(\mathrm{MJ} / \mathrm{kg})=1.64+0.42 \times$ fat $\%$.

The data obtained was analyzed by using ANOVA within SAS program (Anonymous 2001) as in the following model:

$$
\mathrm{Y}_{\mathrm{ijk}}=\mu+\mathrm{T}_{\mathrm{i}}+\mathrm{S}_{\mathrm{j}}+\mathrm{TS}_{(\mathrm{ij})}+\mathrm{e}_{\mathrm{ijk}}
$$

Where:

$\mathrm{Y}_{\mathrm{ijk}}=$ Observational value of $\mathrm{K}^{\mathrm{th}}$ animal.

$\mu \quad=$ Overall mean

$\mathrm{T}_{\mathrm{i}} \quad=$ Effect of treatment $(\mathrm{i}=$ treated, non treated $)$

$\mathrm{S}_{\mathrm{j}} \quad=$ Stage of lactation $(\mathrm{j}=1,2,3,4,5)$

$\mathrm{TS}_{(\mathrm{ij})}=$ Effect of interaction between $_{\mathrm{i}}$ treatment and $\mathrm{j}_{\mathrm{j}}$ stage of lactation 
$\mathrm{e}_{\mathrm{ij}} \quad=$ Experimental error assumed to be NID with $\left(0, \sigma^{2} \mathrm{e}\right)$.

RESULTS AND DISCUSSION

It appears from Table (2) that both DM and ME intake were almost similar in both treated and control groups. Protected soybean meal with formaldehyde resulted in a decrease of estimated RDP as compared to control group 6.67 vs $8.37 \mathrm{gm} / \mathrm{MJ}$ ME (Table 3). It is clear from Table (3) that RDP content was higher in control group by $7.17 \%$, while a decrease $-14.59 \%$ was noticed in treated group when compared with the Anonymous (1980) recommendation (7.81 gm RDP/ MJ ME).

Table (2): DM, ME and protein fractions intake and \%, RDP required and rumen UDP Status.

\begin{tabular}{|c|c|c|}
\hline Item & Control & Treatment \\
\hline Daily DM intake (Kg/Animal) & 0.846 & 0.850 \\
\hline Daily ME intake (MJ/Animal) & 8.76 & 8.81 \\
\hline RDP\% * & 70.54 & 56.25 \\
\hline UDP\% * & 29.46 & 43.75 \\
\hline RDP intake (gm/day) & 73.36 & 58.77 \\
\hline UDP intake (gm/day) & 30.64 & 45.72 \\
\hline RDP required (gm/day) $* *$ & 68.42 & 68.81 \\
\hline Rumen status of RDP (gm/day) *** & +4.74 & -10.04 \\
\hline
\end{tabular}

$*$ Expressed according to (Anonymous, 1980): $($ Kassem,1986).** $=7.81 \times \mathrm{ME}$ intake ((Anonymous, 1980). *** Intake RDP - required RDP.

Feeding Meriz does treated soybean meal increased significantly $(\mathrm{P}<0.001)$ daily milk production $631.44 \pm 20.39 \mathrm{gm} /$ day as compared to control $486.89 \pm 10.9 \mathrm{gm} /$ day (Table 4). Also, an increase of $29.69 \%$ in total milk yield (TMY) $44.20 \pm 2.75 \mathrm{Kg}$ was achieved when does fed treated soybean meal as compared to control group $34.08 \pm 0.94 \mathrm{Kg}$. It is known that treating SBM with formaldehyde reduced its ruminal degradation without adversely affecting its intestinal protein digestion and absorption.(Yoruk et al., 2006), therefore, this results may due to an increase in estimated MP availability in formaldehyde treated group (Table 3.) which may resulted in a higher yield. Similar results were obtained earlier by Chowdhury et al., (2002), and El-Shabrawy (2006) who reported an increase in milk yield in goats fed formaldehyde treated soybean meal compared to those fed untreated soybean meal. On the other hand Hadjipanayiotou and Morand-Fehr, (1991) showed a non significant increase in FCM yield of Damascus goat with protected soybean meal.

Also, result indicate that protection of soybean meal increased significantly $(\mathrm{P}<0.001)$ fat percentage $4.14 \pm 0.13$ and yield $25.45 \pm 0.74 \mathrm{gm} / \mathrm{day}$ as compared to control group (Tables 4), this could be attributed to increase digestibility of the most nutrient and TDN as a result of protein protection (Kassab, et al., 2009). Similarly, other workers noted that protected soybean meal increased the fat percentage of German Fawn Goat (Chowdhury et al., 2002), Awassi ewes (Sulaiman, 2004), cows (Ashes et al., 1992). However, this result disagree with those of Dosky, (2007) who reported that formaldehyde treated concentrate ration have no effect on milk fat percentage in Karadi ewes. Also, data revealed a significant $(\mathrm{P}<0.001)$ increase in milk protein percentage $4.86 \pm 0.05$ and yield $30.73 \pm 1.02 \mathrm{gm} /$ day for Meriz does fed 
treated soybean meal as compared to control (Tables 4). This increase may due to an increase in protected protein reach small intestine as well as microbial protein produced in the rumen (Anonymous, 1984).

Table (3): RDP (gm/MJ ME), Crude and true Microbial protein (gm/day),UDP (gm/day) in rumen and Estimated MP (gm/day).

\begin{tabular}{|c|c|c|}
\hline Item & Control & Treatment \\
\hline Estimated RDP(gm/MJ ME) & 8.37 & 6.67 \\
\hline Crude Microbial protein (gm/day) $*$ & 84.1 & 84.57 \\
\hline True Microbial protein (gm/day) $* *$ & 63.08 & 63.43 \\
\hline UDP (gm/day) in rumen & 30.64 & 45.72 \\
\hline Estimated MP (gm/day) $* * *$ & 59.74 & 69.59 \\
\hline
\end{tabular}

* 9.6 xdaily intake ME MJ ((Anonymous,1998). ** Crude Microbial protein $\times 0.75$ ((Anonymous, 1998) $* * *$ (True Microbial protein + UDP) $\times 0.85 \times 0.75$ ( by assuming true small intestine digestibility is $0.85(($ Anonymous, 1998) and AA using efficiency 0.75 ((Anonymous, 1980).

Moreover, It is known that the fraction of dietary protein that escapes ruminal fermentation may, in virtue of its amino acid composition, supplement the protein of microbial origin in the duodenum. In this way, the protein content of the milk can be increased (Chandler, 1995; Santos and Huber, 1996; Sanza Sampelayo et al., 1999). Therefore, chemical treatment of soybean meal improves protein percentage through an increase of UDP (Table3.) and subsequently the potential supply of amino acids that generated from the enzymatic digestion of the escaped protein portion to the small intestine (Kassab, et al., 2009). Our results are in accordance with the finding of ElShabrawy (2006) who found that protein percentage in goat milk was greater $(\mathrm{P}<0.05)$ with formaldehyde treated soybean meal than of untreated one. energy

Protected soybean meal significantly $(\mathrm{P}<0.001)$ increased daily milk

(3.38MJ/kg) of Meriz goat when compared to control $3.03 \mathrm{MJ} / \mathrm{kg}$ (Table 4). This could be attributed to an increase in fat percentage in formaldehyde protected soybean meal group (Table 4). Similar results were noted by Chowdhury et a.l., (2002) who noted that protected protein increased net energy (NE) content of milk in German Fawn Goat. Also in Karadi ewes, Kassem et al (2009) noted a significant increase $(\mathrm{P}<0.05)$ in milk NE secretion when the animals fed formaldehyde protected concentrate. It seems that the peak of daily milk yield was occurred at second stage of the lactation and then decline towards the end of lactation. Fat $\%$ and milk energy increased steadily from the start to the termination of trail. Protein yield decreased with the advances of lactation ( Table 2.).

Body weight of Meriz goat fed protected or unprotected soybean meal is presented in Table (4). Result indicates a non significant increase in body weight gain for both treatments with advancing of lactation. Our results are in agreement with Salih (2008) and Dosky (2007) who noted a non significant increase in final body weight for Awassi and Karadi ewes fed formaldehyde treated concentrate respectively. While disagree with those of Kassem (2002) 
who found a significant increase in final body weight for cows fed silage with formaldehyde treated barley when compared to those fed untreated barley. Based on the finding of the present study it may be conclude that providing dietary undegradable protein had a beneficial effect on milk yield during lactation period in Meriz goat. Further studies with a greater number of animals fed different levels of dietary protein are needed. 


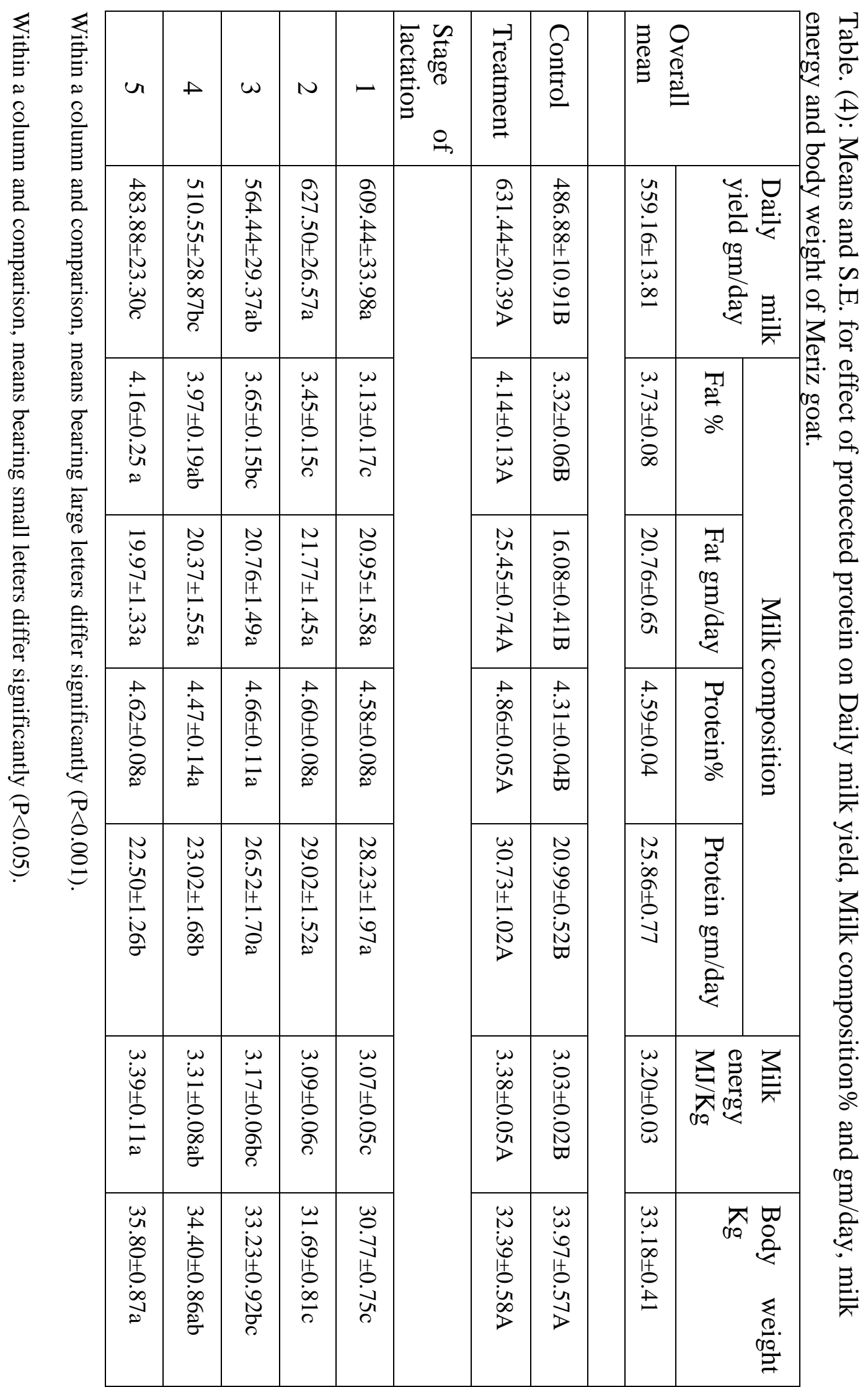


Acknowledgment: the authors would like to thank prof. Dr. Jalal E. AlKass, Department of animal production for his valuable help in reading the manuscript.
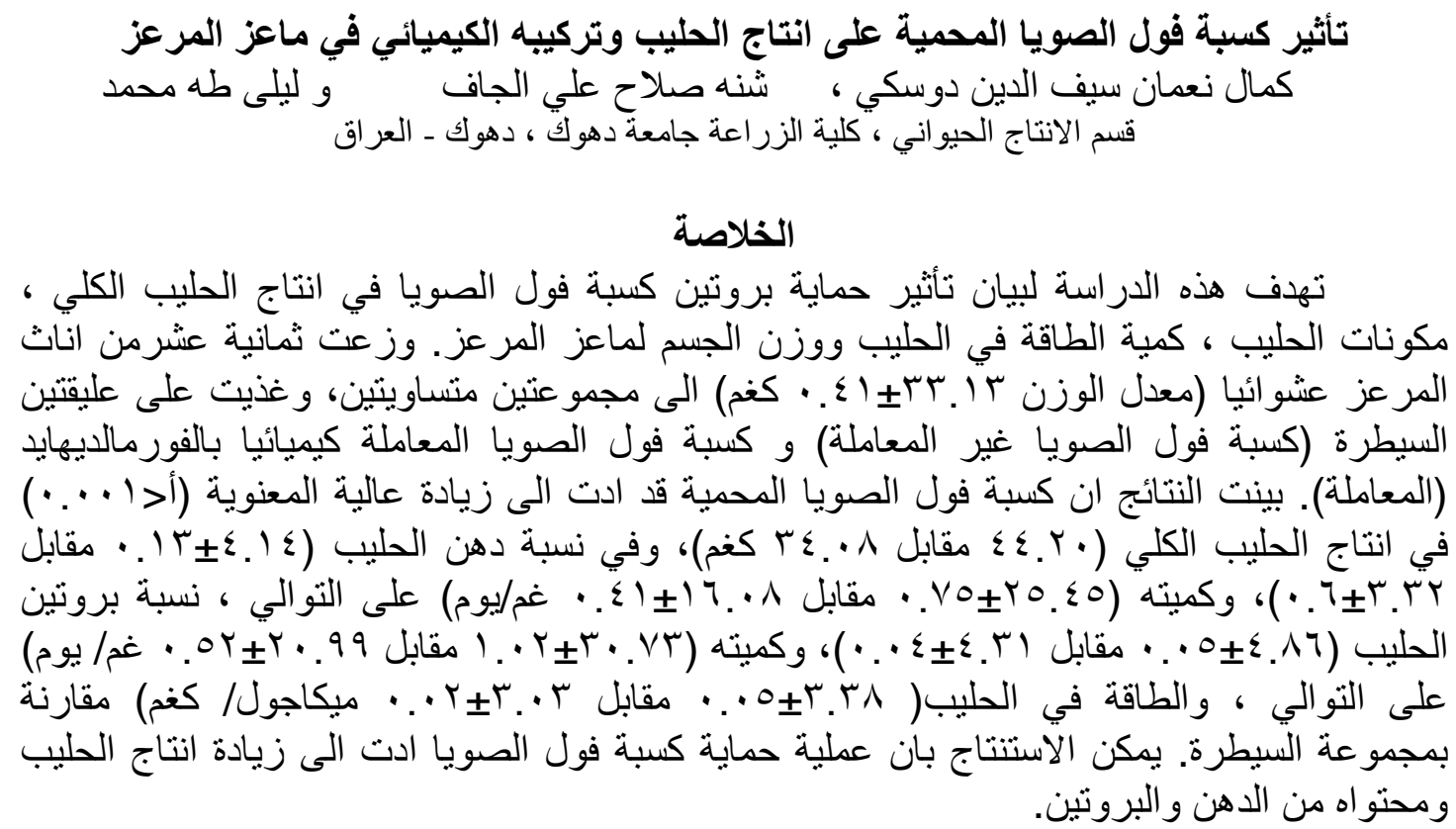

\section{REFERENCES}

Anonymous. (1998). The Nutrition of Goats, Agricultural Feed Research Council CAB International, Wallingford, UK.

Anonymous (1980). The Nutrient Requirement Of Ruminant Livestock. Agricultural Research Council. Commonwealth Agricultural Bureaux. Surry: the Gersham Press.

Anonymous (1984). The Nutrient Requirement Of Ruminant Livestock. Agricultural Research Council. Suppl. 1 Commonwealth Agricultural Bureaux, Farnham Royal. Slough.

Anonymous (1980). Official Method of Analysis of Association of Official Analytical Chemists. 13th ed Washington, D. C., U. S. A.

Anonymous (2002). Statistical Analysis System User's Guide. SAS Institute, Cary, Inc. N. C., USA.

Alkass, J. E. and K. H. Juma. (2005). Small ruminant breeds of Iraq. In: Characterization of Small Ruminant Breeds in West Asia and North Africa (Editor, Luis Iniguez). Vol. 1. West Asia. International Center of Agriculture Research in the Dry Areas (ICARDA)., Aleppo, Syria, pp.63101.

Al-khawaja, A. K. ; S. A. Matti ; R. F. Asadi ; K. M. Mokhtar and S. H. Aboona, (1978). The Composition and Nutritive Value Of Iraqi Feedstuffs, Division Publication, Ministry of Agriculture, Iraq.

Ashes, J. R. ; P. ST. Vincent Welch ; S. K. Gulati, ; T. W. Scott and G. H. Brown (1992). Manipulation of the fatty acid composition of milk by feeding protected canola seeds. J. Dairy Sci., 75:1090-1096.

Brun-Bellut, J. ; G. Blanchart and B. Vignon (1990). Effect of Rumendegradable protein concentration in diets in digestion, nitrogen utilization and milk yield by dairy goats. Small Ruminant Research 3: 575-581. 
Chandler, P. (1995). Amino acid nutrition of dairy cows advances but still has ways to go. Feedstuffs, 67(33):11-14.

Chowdhury, S. A. ; H. Rexroth ; C. Kijora and K. J. Peters (2002). Lactation performance of German fawn goat in relation to feeding level and dietary protein protection. Asian-Aus. J. Anim. Sci., 15: 222-237.

Dosky, K. N. S. (2007). Effect Of Formaldehyde Treated Concentrate On Productive Performance and Some Blood Biochemical Parameters in Karadi sheep. Ph. D. Thesis- College of Agric. and Forestry, Mosul Univ. Mosul- Iraq.

Economides, S. (1986). Comparative studies of sheep and goat milk yield, composition and growth rate of lambs and kids. J. Agric. Sci. (Camb), 106: 477-484.

El-Shabrawy, H. M. (2006). Performance of goats fed protected protein during gestation and lactation. Egyptian J. Sheep, Goat and Desert Animals Sci., $1: 213$.

Hadjipanayiotou, M. and P. Morand-Fehr. (1991). Intensive feeding of dairy goats. In: Goat Nutrition. (Ed. P. Morand-Fehr). Pudoc, Wageningen. Pp. 197-208.

Kassab, A. Y.; A. A. Abdel-Ghani ; G. M. Solouma1; E. B. Soliman and A. K. Abd El moty. (2009). Lactation performance of Sohagi sheep as affected by feeding canola protected protein. Egyptian Journal of Sheep \& Goat Sciences. 4: 65-78.

Kassem, M. M. (1986). Feed Intake and Milk Production In Dairy Cows With Special References To Diet Containing Grass and Lucerne Silage With Barley Supplements. Ph. D. Thesis. University of Glasgow, Scotland.

Kassem, M. M. ; P. C. Thomas ; D. G. Chamberlain and S. Robertson (1987). Silage intake and milk production in cows given barley supplements of reduced ruminal degradability. Grass and Forage Science. 42: 175-183.

Kassem, M. M. (2002). Comparative study of cellulolytic in vitro of rations containing different starch levels. Proceeding of the $2^{\text {nd }}$ Congress on Recent Technologies In Agriculture, Cairo University 28-30 October, 2002. Vol. III: 559-563.

Kassem, M. M. ; Q. Z. Shams El-deen, and H. A. Sulaiman (2007). Effect of feeding ration treated with formaldehyde on milk production and composition and lamb growth of Awassi sheep. 10 ${ }^{\text {th }}$ Egyptian Conf. Dairy Sci. and Tech. pp. 1-14.

Kassem, M. M. ; K. N. S. Dosky and A. Abd El-Ghany. (2009). The effect of using reduced ruminal degradability concentrated ration on milk secretion and some biochemical blood measurements in Karadi ewes under pasture condition. Egyptian J. Nutrition and Feeds. 12 (3) Special Issue: 337-348.

Mir, Z.; G. K. Macleod ; J. G. Buchanan-Smith ; D.G. Grieve and W.L. Grovum (1984). Methods for protecting soybean and canola proteins from degradation in the rumen. Can. J. Anim. Sci. 64: 853-865.

Mustafa, A. F.; J. J. Mckinnon and D. A. Christensen. (2000). Protection of canola (low glucosinolate rapseed) meal and seed protein from ruminal degradation, Asian-Aus. Sci. 13: 535-542.

Oldham, J. D.(1984). Protein-energy interrelationships in dairy cows. J. Dairy Sci.,67: 1090-1114.

Salih, A. M. (2008). Effect Of Different Levels Of Protein In Formaldehyde Treated Rations On Performance and Some Biochemical Traits In Awassi sheep. Ph. D. Thesis, Mosul Univ. Mosul-. Iraq. 
Salih, M. N. (2009). Effect Of Using Reduced Degradability Fodder On Reproductive and Productive Performance Of Super Awassi sheep. Ph. D. Thesis, Mosul Univ. Mosul-. Iraq.

Santos, F. P. and J. T. Huber (1996). Quality of bypass proteins fed to high producing cow is important. Feedstuffs., 68(34)12-13, 15.

Sanza Sampelayo, M. R. ; M. L. Perez ; F. GIL Extremera ; J. J. Boza and J. Boza (1999). Use of different dietary protein sources for lactating goats: milk production and composition as functions of protein degradability and amino acid composition. J. Dairy Sci., 82:555-565.

Shams El-deen, Q. Z. (2005). Effect of suckling regiem and weaning age on milk yield and composition and kids performance of local Al-Mariz goat. Mesopotamia J. of Agric. Vol (33) No. (1): 44-51.

Shams El-deen, Q. Z. ; I. Abdulhameed ; N. H. Qadir and I. H. Abdal. (2006). Using different source of feeds in pregnant maiz Al-Mariz does rations and their effect on growth of kids, milk yield and composition. AlTaqani.19 (3): 87-93.

Sulaiman, H. A. (2004). Effect Of Feeding Ration Treated With Formaldehyde On Milk Production and Composition and Lambs Growth. M. Sc. Thesis, Mosul Univ. Mosul-. Iraq.

Varvikko, T. ; J. E. Lindberg ; J. Setela and L. Syrjala-Qvist, (1983). The effect of formaldehyde treatment of soyabean meal and rapeseed meal on the amino acids profiles and acid-pepsin solubility of rumen undegraded protein. J. Agric. Sci. (Camb.); 101: 603-612.

Yoruk, M. A. ; T. Aksu. ; M. Gul. and D. Bolat. (2006). The effect of soybean meal treated with formaldehyde on amount of protected protein in the rumen and absorption of amino acid from small intestines. Turk. J. Vet. Anim. Sci. 30: 457-463. 